\title{
Effect of Cold Storage on the Germination Success of Four Stonecrop Species
}

\author{
Kathryn L. McDavid ${ }^{1}$, David L. Sanford, and Robert D. Berghage
}

Additional Index words. Sedum acre, Sedum forsterianum, Sedum reflexum, Sedum selskianum, seed storage, germination percentage, seed age, green roof

SUMMARY. Green roof construction is constrained by cost of labor to install the plant material. Optimizing seed germination and establishment could significantly reduce installation costs but would require specific growing conditions that are difficult to provide during installation. Plants of the stonecrop (Sedum) genus are commonly used for the roof top because they will tolerate the high temperatures. This study compared the germination rates of four stonecrop species \{goldmoss sedum ( $\mathrm{Sedum}$ acre), 'Oracle' sedum (Sedum forsterianum), blue spruce sedum (Sedum reflexum), and amur sedum [Sedum selskianum (synonm Phedimus selskianum)]\} at two temperatures, 70 and $90^{\circ} \mathrm{F}$, following storage of seed in dry, cool $\left(40^{\circ} \mathrm{F}\right)$ conditions of different durations $\left(54,98,157,197,255\right.$, or 343 days). At $70{ }^{\circ} \mathrm{F}$ seed of goldmoss sedum, 'Oracle' sedum, and blue spruce sedum produced minimum germination rates of $60 \%$ at 21 days in seed stored for $54,98,157,197,255$, or 343 days. Goldmoss sedum, 'Oracle' sedum, and blue spruce sedum showed reduced germination in $90^{\circ} \mathrm{F}$, probably due to temperature-induced dormancy. Amur sedum had germination of at least $83 \%$ at 21 days in both temperatures tested. As amur sedum germination rates appear to be unaffected in the temperatures tested, it could provide an excellent seed for use on green roofs where ideal temperatures are rarely available.

$\mathrm{G}$ reen roofs are being used throughout the United States to reduce storm water runoff, improve rain water and air quality, and reduce the effect of urban heat islands (Snodgrass and Snodgrass, 2006). One of the primary limitations to their use is the cost of installation. Traditional methods for plant installation are through the use of broadcast cuttings, plugs, or nursery containers. Seeds are rarely used due to low rates of germination when under nonoptimal conditions and the long time required for seedling establishment on a roof.

Recent research indicates that under optimal conditions on a green roof, seeds can provide a viable option for installation (Monterusso et al., 2005). Further research is needed to determine the best species to use for seed installation under diverse conditions. Traditional installation methods have shown that stonecrop species are

Department of Plant Science, The Pennsylvania State University, Tulpehocken Road, P.O. Box 7009, Reading, PA 19610

This paper is a portion of a dissertation submitted by one of the authors.

We thank Benary Seed for supplying the seeds used in this study.

${ }^{1}$ Corresponding author. E-mail: kmcdavid460@gmail. com

doi: 10.21273/HORTTECH03587-16 optimal for use on green roofs due to their high survival rates after establishment in the mid-Atlantic region of the United States (Heinz, 1985; Snodgrass and Snodgrass, 2006). Seeds of stonecrop species have been used as a green roof installation method under ideal temperature and moisture conditions (Monterusso et al., 2005).

Seeds stored for long periods undergo physiological changes leading to lower germination rates (Baskin and Baskin, 1998). Orthodox seeds, such as stonecrop species, can be stored at low moisture content for many years (Hartmann et al., 2011).

There is little information in scientific literature on the effects of storage or germination temperature on germination rates of stonecrop species. Bonde (1965) showed that lanceleaf sedum (Sedum lanceolatum) seed germinated at $92.5 \%$ using growth chambers set at $18^{\circ} \mathrm{C}$. Widow's cross sedum (Sedum pulchellum) seed, grown in 20 or $25^{\circ} \mathrm{C}$, had germination rates of $91 \%$ when seed was stored for 7 months and germination rates at or below $16 \%$ when stored up to 5 months, proving a dormancy existed in the seed (Baskin and Baskin, 1977).

Four species were used in this study: goldmoss sedum, 'Oracle' sedum, blue spruce sedum, and amur sedum. These species were selected based on seed availability and their ability to germinate under a broad range of conditions in the mid-Atlantic region on green roofs. The study temperature of $70{ }^{\circ} \mathrm{F}$ was selected since it resulted in optimal germination in studies of stonecrop germination by Baskin and Baskin (1977) and Bonde (1965). Lundholm et al. (2010) suggested that nonvegetated green roof media can reach an average of $5.5^{\circ} \mathrm{F}$ warmer than the ambient air temperatures at midday, therefore, this work evaluated germination of these four species at $90^{\circ} \mathrm{F}$ as well. The objective of this study was to determine whether seed storage impacts germination rates at 70 or $90{ }^{\circ} \mathrm{F}$ of the four stonecrop species.

\section{Materials and methods}

Seeds of four stonecrop species (goldmoss sedum, 'Oracle' sedum, blue spruce sedum, and amur sedum) were received from Benary Seed (Dekalb, IL) on 20 Dec. 2010. Benary reported the seeds were viable with germination rates of at least $85 \%$ for each species when tested in late spring or early Summer 2010. Therefore, the seeds were at least 6 to 8 months old when received. The seeds were placed in dry, cool storage at $40{ }^{\circ} \mathrm{F}$. Germination tests were performed at $54,98,157,197,255$, or $343 \mathrm{~d}$ after receipt of the seeds. Due to a malfunction in a growth chamber, data for the $343 \mathrm{~d}$ storage treatment germinated in the $90{ }^{\circ} \mathrm{F}$ temperature was contaminated.

At each germination test, 100 seeds of each species were removed from storage and separated into groups of 25 for testing at each of the two temperatures. For each species, 25 seeds were placed on a petri dish with one piece of filter paper and $1.5 \mathrm{~mL}$ of deionized water, providing four replications per temperature treatment.

\begin{tabular}{llll}
\hline $\begin{array}{l}\text { Units } \\
\begin{array}{l}\text { To convert U.S. to SI, } \\
\text { multiply by }\end{array}\end{array}$ & U.S. unit & SI unit & $\begin{array}{l}\text { To convert SI to U.S., } \\
\text { multiply by }\end{array}$ \\
\hline 29.5735 & $\mathrm{fl} \mathrm{oz}$ & $\mathrm{mL}$ & 0.0338 \\
$\left({ }^{\circ} \mathrm{F}-32\right) \div 1.8$ & ${ }^{\circ} \mathrm{F}$ & ${ }^{\circ} \mathrm{C}$ & $\left({ }^{\circ} \mathrm{C} \times 1.8\right)+32$
\end{tabular}


The petri dishes were double wrapped with plastic paraffin film (parafilm; Beemis NA, Neenah, WI) randomized, and placed in sets of four in clear, resealable plastic bags. The petri dishes were then placed in a growth chamber (Hoffman Manufacturing, Albany, OR; Percival Scientific, Boone, IA; or Controlled Environments, Winnipeg, MB, Canada) in a completely randomized design at either 70 or $90^{\circ} \mathrm{F}\left( \pm 1.5^{\circ} \mathrm{F}\right)$ with 12-h light/dark cycles. Deionized water was added to the petri dishes as necessary to provide free water without floating the seeds.

Using dissecting microscopes, data were collected every day for $21 \mathrm{~d}$ and seeds were considered germinated when radicle emergence was at least one quarter the size of the seed. The petri dishes were rerandomized each day after data collection. Within each species, an analysis of variance was conducted using the PROC MIXED procedure in SAS (version 9.3; SAS Institute, Cary, NC) based on a completely randomized design for each temperature on the final germination rate at $21 \mathrm{~d}$ and on the time to $50 \%$ germination (T50). Main effect means (storage time) were separated using Tukey's test and a probability value of 0.05 .

\section{Results and discussion}

Goldmoss sedum. At 70 and $90{ }^{\circ} \mathrm{F}$, there were significant differences between time of storage and either germination rate or T50. When temperatures are close to $70{ }^{\circ} \mathrm{F}$, such as in late spring or early summer in the mid-Atlantic region, seed stored for 157,255 , or $343 \mathrm{~d}$ after receipt of seed is recommended as they produced the highest day 21 germination percentages at $92 \%, 78 \%$, and $89 \%$, respectively (Table 1).

In contrast, day 21 germination percentages decreased as the seeds matured when grown in a $90{ }^{\circ} \mathrm{F}$ growth chamber. Under higher temperatures, such as observed later in the summer, seed stored for shorter periods $(54,98$, or $157 \mathrm{~d}$ ) is recommended for use, even though the highest germination on day 21 for any treatment was less than $60 \%$. The lower germination rates under the higher temperature could indicate a mild temperature-induced dormancy; Bewley and Black (1982) suggest continuing germination tests at even higher temperatures to produce the temperature that would cause full dormancy.
Together with the T50 data, at $70{ }^{\circ} \mathrm{F}$, seed stored for $157 \mathrm{~d}$ is recommended for the fastest and highest germination with a T50 of $1.500 \mathrm{~d}$ and $92 \%$ germination on day 21 . Seed stored for 255 and $343 \mathrm{~d}$ had similar day 21 germination but it took significantly longer to reach T50 (4.250 and $4.375 \mathrm{~d}$, respectively). In the 90 ${ }^{\circ} \mathrm{F}$ temperature, seeds stored for 54 or $157 \mathrm{~d}$ provided the highest $(58 \%$ and $29 \%$, respectively) and quickest (4.250 and $2.250 \mathrm{~d}$, respectively) final germination rates.

'Oracle' SEDUm. There were no significant differences in day 21 germination percentages for 'Oracle' sedum seeds germinated in the $70{ }^{\circ} \mathrm{F}$ growth chamber. After $21 \mathrm{~d}$ in the growth chamber, seeds at all ages showed final germination between $82 \%$ and $98 \%$ (Table 2). Germination percentages in the $90{ }^{\circ} \mathrm{F}$ growth chamber were below $10 \%$ for all seed ages, with seed stored for $255 \mathrm{~d}$ showing the lowest final germination rate on day 21 at $0 \%$. These results demonstrate that 'Oracle' sedum seeds are sensitive to increased temperatures and the potential for high temperatures to cause dormancy within the seeds. This physiological response may ensure that the seeds only germinate in the cooler months of the year to ensure germination and plant success. Similar temperature-induced dormancy has been shown in widow's cross sedum as seeds germinated over $90 \%$ in $20.0^{\circ} \mathrm{C}$ day $/ 10.0^{\circ} \mathrm{C}$ night temperatures and under $10 \%$ in $35{ }^{\circ} \mathrm{C}$ day $/ 20.0^{\circ} \mathrm{C}$ night temperatures (Baskin and Baskin, 1977). If consistent temperatures around $70^{\circ} \mathrm{F}$ could be provided, all seed would produce successful germination; unfortunately, it is nearly impossible to provide such optimal temperature conditions on a green roof, except for a short period in late spring or early summer (Snodgrass and Snodgrass, 2006).

Significant differences occurred in the T50 data in seeds grown in the $70{ }^{\circ} \mathrm{F}$ growth chamber. Seed stored for $157 \mathrm{~d}$ showed the quickest T50 at $2.250 \mathrm{~d}$ and is recommended for the fastest and highest germination if temperatures can be provided around $70{ }^{\circ} \mathrm{F}$. The T50 in the $90{ }^{\circ} \mathrm{F}$ showed no statistically significant differences between storage times, but due to the low final germination rates at $21 \mathrm{~d}$ (less than 10\%), 'Oracle' sedum is not recommended for use.

Table 1. Final germination percentage at $21 \mathrm{~d}$ and time to $50 \%$ germination (T50) of goldmoss sedum after different durations of storage grown in a 70 or $90{ }^{\circ} \mathrm{F}\left(21.1\right.$ or $\left.32.2^{\circ} \mathrm{C}\right)$ growth chamber with a 12 -h photoperiod.

\begin{tabular}{lllllc}
\hline & \multicolumn{2}{c}{ Final germination (\%) } & & \multicolumn{2}{c}{ T50 (d) } \\
\cline { 2 - 3 } Storage time (d) & $\mathbf{7 0}{ }^{\circ} \mathbf{F}$ & $\mathbf{9 0}{ }^{\circ} \mathbf{F}$ & & $\mathbf{7 0}^{\circ} \mathbf{F}$ & $\mathbf{9 0}^{\circ} \mathbf{F}$ \\
\hline 54 & $63.0 \mathrm{c}^{\mathrm{z}}$ & $58.0 \mathrm{a}$ & & $4.250 \mathrm{~b}$ & $4.250 \mathrm{ab}$ \\
98 & $66.0 \mathrm{bc}$ & $34.0 \mathrm{ab}$ & & $6.375 \mathrm{c}$ & $5.125 \mathrm{~b}$ \\
157 & $92.0 \mathrm{a}$ & $29.0 \mathrm{ab}$ & & $1.500 \mathrm{a}$ & $2.250 \mathrm{a}$ \\
197 & $72.0 \mathrm{bc}$ & $13.0 \mathrm{~b}$ & & $3.500 \mathrm{ab}$ & $2.625 \mathrm{ab}$ \\
255 & $78.0 \mathrm{ab}$ & $23.0 \mathrm{~b}$ & & $4.250 \mathrm{~b}$ & $4.625 \mathrm{ab}$ \\
343 & $89.0 \mathrm{a}$ & - & & $4.375 \mathrm{bc}$ & - \\
\hline
\end{tabular}

${ }^{\mathrm{z}}$ Within the columns, means $(\mathrm{n}=4)$ followed by different letters are significantly different (Tukey's multiple comparison test at $P<0.05)$.

Table 2. Final germination percentage at $21 \mathrm{~d}$ and time to $50 \%$ germination (T50) of 'Oracle' sedum after different durations of storage grown in a 70 or $90{ }^{\circ} \mathrm{F}\left(21.1\right.$ or $\left.32.2^{\circ} \mathrm{C}\right)$ growth chamber with a 12 -h photoperiod.

\begin{tabular}{lccrrr}
\hline & \multicolumn{2}{c}{ Final germination (\%) } & & \multicolumn{2}{c}{ T50 (d) } \\
\cline { 2 - 3 } Storage time (d) & $\mathbf{7 0}{ }^{\circ} \mathbf{F}$ & $\mathbf{9 0}{ }^{\circ} \mathbf{F}$ & & ${ }^{\circ} \mathbf{F}$ & $\mathbf{9 0}^{\circ} \mathbf{F}$ \\
\hline 54 & 89.0 & $10.0 \mathrm{a}^{\mathrm{z}}$ & & $8.625 \mathrm{~b}$ & 9.000 \\
98 & 87.0 & $8.0 \mathrm{a}$ & & $13.250 \mathrm{c}$ & 9.250 \\
157 & 98.0 & $10.0 \mathrm{a}$ & & $2.250 \mathrm{a}$ & 11.875 \\
197 & 91.0 & $3.0 \mathrm{ab}$ & & $8.000 \mathrm{~b}$ & 9.875 \\
255 & 82.0 & $0.0 \mathrm{~b}$ & & $9.500 \mathrm{~b}$ & 0.000 \\
343 & 85.0 & - & & $6.875 \mathrm{~b}$ & - \\
\hline
\end{tabular}

${ }^{\mathrm{z}}$ Within the columns, means $(\mathrm{n}=4)$ followed by different letters are significantly different (Tukey's multiple comparison test at $P<0.05$ ). 
Blue SPRUCE SEDUM. There were no significant differences for the final germination of blue spruce sedum seeds in the $70{ }^{\circ} \mathrm{F}$ growth chamber, with data ranging between $84 \%$ and $94 \%$ (Table 3). In the $90{ }^{\circ} \mathrm{F}$ growth chamber, day 21 germination for blue spruce sedum seed showed a significant decrease in germination as the seeds were stored for longer periods. Similar to goldmoss sedum and 'Oracle' sedum, a temperature-induced dormancy was potentially activated within the seed when grown in the $90^{\circ} \mathrm{F}$ growth chamber. The temperature-induced dormancy characteristics within goldmoss sedum, 'Oracle' sedum, blue spruce sedum, and widow's cross sedum (Baskin and Baskin, 1977) may indicate that other closely related species within the stonecrop genus will also show a temperature-induced dormancy.

Seed stored for $157 \mathrm{~d}$ is recommended for use in $70{ }^{\circ} \mathrm{F}$ temperatures based on the final germination at $21 \mathrm{~d}$ (84\%) and the T50 results, where seed stored for $157 \mathrm{~d}$ germinated the quickest at $2.500 \mathrm{~d}$ in the $70{ }^{\circ} \mathrm{F}$ growth chamber. In the $90^{\circ} \mathrm{F}$ growth chamber, seed stored for $54 \mathrm{~d}$ is recommended for the quickest $(5.125 \mathrm{~d})$ and highest (40\%) germination.

Table 3. Final germination percentage at $21 \mathrm{~d}$ and time to $50 \%$ germination (T50) of blue spruce sedum after different durations of storage grown in a 70 or $90{ }^{\circ} \mathrm{F}\left(21.1\right.$ or $\left.32.2^{\circ} \mathrm{C}\right)$ growth chamber with a 12 -h photoperiod.

\begin{tabular}{lccccc}
\hline & \multicolumn{2}{c}{ Final germination (\%) } & & \multicolumn{2}{c}{ T50 (d) } \\
\cline { 2 - 3 } \cline { 5 - 6 } Storage time (d) & $\mathbf{7 0}{ }^{\circ} \mathbf{F}$ & $\mathbf{9 0}{ }^{\circ} \mathbf{F}$ & & $\mathbf{7 0}^{\circ} \mathbf{F}$ & $\mathbf{9 0}{ }^{\circ} \mathbf{F}$ \\
\hline 54 & 94.0 & $40.0 \mathrm{a}^{\mathrm{z}}$ & & $3.000 \mathrm{ab}$ & $5.125 \mathrm{~b}$ \\
98 & 92.0 & $4.0 \mathrm{~b}$ & & $3.500 \mathrm{bc}$ & $2.250 \mathrm{ab}$ \\
157 & 84.0 & $7.0 \mathrm{~b}$ & & $2.500 \mathrm{a}$ & $7.625 \mathrm{~b}$ \\
197 & 85.0 & $0.0 \mathrm{~b}$ & & $3.500 \mathrm{bc}$ & $0.000 \mathrm{a}$ \\
255 & 90.0 & $0.0 \mathrm{~b}$ & & $4.250 \mathrm{c}$ & $0.000 \mathrm{a}$ \\
343 & 92.0 & - & & $4.250 \mathrm{c}$ & - \\
\hline
\end{tabular}

${ }^{\mathrm{z}}$ Within the columns, means $(\mathrm{n}=4)$ followed by different letters are significantly different (Tukey's multiple comparison test at $P<0.05$ ).

Table 4. Final germination percentage at $21 \mathrm{~d}$ and time to $50 \%$ germination (T50) of amur sedum after different durations of storage grown in a 70 or $90{ }^{\circ} \mathrm{F}$ $\left(21.1\right.$ or $32.2^{\circ} \mathrm{C}$ ) growth chamber with a 12 -h photoperiod.

\begin{tabular}{lccccc}
\hline & \multicolumn{2}{c}{ Final germination $(\%)$} & & \multicolumn{2}{c}{ T50 (d) } \\
\cline { 2 - 3 } \cline { 5 - 6 } Storage time (d) & $\mathbf{7 0}{ }^{\circ} \mathbf{F}$ & $\mathbf{9 0}^{\circ} \mathbf{F}$ & & $70^{\circ} \mathbf{F}$ & $\mathbf{9 0}{ }^{\circ} \mathbf{F}$ \\
\hline 54 & 89.0 & $89.0 \mathrm{ab}^{\mathrm{z}}$ & & $3.500 \mathrm{~b}$ & $4.000 \mathrm{~b}$ \\
98 & 95.0 & $88.0 \mathrm{ab}$ & & $4.500 \mathrm{c}$ & $4.125 \mathrm{~b}$ \\
157 & 93.0 & $92.0 \mathrm{ab}$ & & $2.250 \mathrm{a}$ & $2.750 \mathrm{a}$ \\
197 & 94.0 & $83.0 \mathrm{~b}$ & & $3.500 \mathrm{~b}$ & $3.375 \mathrm{ab}$ \\
255 & 98.0 & $94.0 \mathrm{a}$ & & $3.500 \mathrm{~b}$ & $3.250 \mathrm{ab}$ \\
343 & 88.0 & - & & $3.875 \mathrm{bc}$ & -
\end{tabular}

${ }^{\mathrm{z}}$ Within the columns, means $(\mathrm{n}=4)$ followed by different letters are significantly different (Tukey's multiple comparison test at $P<0.05$ ).

Amur sedum. There were no significant differences due to storage amur sedum seeds grown in the mination was between $88 \%$ and $98 \%$ (Table 4). Final germination on day in the $90{ }^{\circ} \mathrm{F}$ temperature ranged In the $70{ }^{\circ} \mathrm{F}$ growth chamber, amur sedum seeds reached T50 the astest when seeds were stored for d $(2.250 \mathrm{~d})$, whereas seeds in the the fastest when seeds were stored 157,197 , or $255 \mathrm{~d}(2.750,3.375$, or $3.250 \mathrm{~d}$, respectively).

Amur sedum seeds showed final Aming sedh on these final germination rates day $2 \mathrm{l}$ in both temperatures and thus, seeds would have the best potent for seed establishment on a green roof as the temperatures on a green roof ied, no temperature-induced dormancy was observed in this study, presumably due to the official scientific classification for amur sedum being Phedimus selskianus, which results in a more distant relationship to the other stonecrop species tested. This name was officially changed in 1995 (Eggli, 2003), although many publications and commercial plant and seed sources still reference it as a stonecrop species.

\section{Conclusion}

Using a mixture of seeds, basing the mixture on germination data at several temperatures and seed ages, would provide a respectable and successful plant palette for seed installation on a green roof. A seeding mixture planted in the late spring or early summer could be drastically different from a seeding mixture being used in the blazing heat of summer. In late spring or early summer, when the high temperatures do not fluctuate much from $70{ }^{\circ} \mathrm{F}$, a mixture of seed from any of the four species at any age in this study could be used to successfully install a green roof. However, as the high temperatures increase later in summer, amur sedum is the only species that is currently recommended for use at any seed age tested. Goldmoss sedum and blue spruce sedum seed could also be used in higher temperatures but must be used as soon as possible after receipt as increased storage time led to significantly lower germination rates.

\section{Literature cited}

Baskin, J.M. and C.C. Baskin. 1977. Germination ecology of Sedum pulchellum Michx. (Crassulaceae). Amer. J. Bot. 64(10):1242-1247.

Baskin, C.C. and J.M. Baskin. 1998. Seeds: Ecology, biogeography, and evolution of dormancy and germination. Academic Press, San Diego, CA.

Bewley, J.D. and M. Black. 1982. Physiology and biochemistry of seeds in relation to germination. Springer-Verlag, New York, NY.

Bonde, E.K. 1965. Further studies on the germination of seeds of Colorado alpine plants. Series in Biology. Paper 32. CU Scholar, Boulder, CO.

Eggli, U. (ed.). 2003. Illustrated handbook of succulent plants: Crassulaceae. Springer-Verlag, New York, NY.

Hartmann, H.T., D.E. Kester, F.T. Davies, Jr., and R.L. Geneve. 2011. Hartmann and Kester's plant propagation 
principles and practices. 8th ed. Prentice Hall, Upper Saddle River, NJ.

Heinz, W. 1985. Results of an experiment on extensive growth of vegetation on roofs. Rasen Grunflachen Bergrunungen 16(3):80-88.
Lundholm, J., J.S. MacIvor, Z. MacDougall, and M. Ranalli. 2010. Plant species and functional group combinations affect green roof ecosystem functions. PLoS One 5(3):e9677.

Monterusso, M.A., D.B. Rowe, and C.L. Rugh. 2005. Establishment and persistence of Sedum spp. and native taxa for green roof applications. HortScience 40:391396.

Snodgrass, E. and L. Snodgrass. 2006. Green roof plants: A resource and planting guide. Timber Press, Portland, OR. 